\title{
Soybean oil and calcium salts of fatty acids as fat sources for Holstein dairy cows in transition period
}

\author{
Óleo de soja e sais de cálcio de ácidos graxos como fonte de gordura para vacas \\ Holandesas no período de transição
}

\section{GANDRA, Jefferson Rodrigues ${ }^{2 *}$ FREITAS JUNIOR, Jose Esler de ${ }^{3}$; MATURNA FILHO, Milton ${ }^{1}$; BARLETTA, Rafael Villela ${ }^{1}$; VERDURICO, Lenita Camargo ${ }^{1}$; RENNÓ, Francisco Palma ${ }^{1}$}

\author{
${ }^{1}$ Universidade de São Paulo, Faculdade de Medicina Veterinária e Zootecnia, Departamento Nutrição e \\ Produção Animal, Pirassununga, São Paulo, Brasil. \\ ${ }^{2}$ Universidade Federal da Grande Dourados, Faculdade de Ciências Agrárias, Dourados, Mato Grosso do \\ Sul, Brasil \\ ${ }^{3}$ Universidade Federal da Bahia, Escola de Medicina Veterinária e Zootecnia, Departamento de \\ Zootecnia, Salvador, Bahia, Brasil. \\ *Endereço para correspondência: jeffersongandra@gmail.com
}

\section{SUMMARY}

This study aimed to evaluate the effects of using different lipid sources in diets for dairy cows during the transition period and early lactation on productive performance and physiological parameters in Holstein cows. The cows were fed with the following diets: 1) control; 2) Refined soybean oil; 3) Calcium salts of unsaturated fatty acids (Megalac-E). Diets were formulated to meet the nutritional requirements of cows during the pre-partum and postpartum period. The experimental diets affected the dry matter intake, body weight, body condition score, and energy balance in the postpartum period. The experimental diets did not affect the biochemical parameters in serum: glucose, total protein, albumin, urea, serum urea nitrogen, total cholesterol, HDL-cholesterol, nonesterified fatty acids, $\beta$-hydroxybutyrate, aspartate aminotransferase, $\quad \gamma$-glutamyl transferase, alkaline phosphatase, also not being observed differences between the contrasts analyzed. The lipid sources soybean oil and calcium salts not directly influence the plasmatic physiological parameters of dairy cows in the period transition. But, fat supplementation in the transition period resulted in a better metabolic status and productive performance, mainly improving energy balance post-partum

Keywords: dairy cows, lipids metabolism, metabolic profile, puerperium

\section{RESUMO}

Objetivou-se com este estudo avaliar os efeitos do uso de diferentes fontes de ácido graxo ômega 6 na dieta de vacas leiteiras no período de transição e início da lactação sobre o desempenho produtivo e bioquímico em vacas da raça Holandesa. As vacas foram alimentadas com as seguintes dietas: 1) controle, 2) óleo de soja refinado, 3) os sais de cálcio de ácidos graxos insaturados (Megalac-E). As dietas foram formuladas para atender às exigências nutricionais das vacas durante o período de préparto e pós-parto, dentro de cada grupo experimental. As dietas experimentais afetaram o consumo de matéria seca, o peso corporal, escore de condição corporal e equilíbrio de energia no período pós-parto. As dietas experimentais não afetaram os parâmetros bioquímicos no soro: glicose, proteína total, albumina, uréia, uréia sérica, colesterol total, HDL-colesterol, ácidos graxos não esterificados, $\quad \beta$-hidroxibutirato, aspartato aminotransferase, $\quad \gamma$-glutamil transferase, fosfatase alcalina, também não sendo observadas diferenças entre os contrastes analisados. As fontes de ácido graxo ômega 6 não influenciaram diretamente o bioquímico de vacas leiteiras no período de transição.

Palavras-chaves: vacas leiteiras, metabolismo lipídico, perfil metabólico, puerpério 


\section{INTRODUCTION}

The supplementation of specific fatty acids to dairy cows during the transition period and early lactation has been used mostly with nutraceutical purpose only and not as a simple source of greater energy content in transition diets. The use of these fatty acids only as an energy source in diets pre-and postpartum is not able to modulate the metabolism of animals aiming better health, and reproduction of the animals. This kind of supplementation would aim only attenuate negative energy balance and not modulate synthesis of steroid hormones, activation of the immune system agents and increased production performance (SILVESTRE et al., 2011).

The fatty acid supplementation is commonly used to diets of lactating cows to meet the increased need for energy intake during early lactation and able to return to a positive energy balance as quickly as possible. However, if the cow does not consume the nutrients required, the energy cost of milk yield should then include the cost of energy to catabolize body tissue to make it available for milk yield (ZACHUT et al., 2010).

Biochemical measurements should be measured in order to establish a complete monitoring aiming a less traumatic passage of the cow by the transition period and early lactation (QUIROZ-ROCHA et al., 2009). The biochemical profile of cows in the transition period is especially monitored by the plasma concentrations of nonesterified fatty acids (NEFA) and $\beta$ hydroxybutyrate (BHBA). Other parameters can also aid the metabolism of these animals completely among them: glucose, serum urea nitrogen (SUN). These metabolites are intimately related with the reduction in dry matter intake between -21 to +21 days postpartum. As consequence, there is increased catabolism of adipose tissue, and elevated plasma concentrations of NEFA in two or three times (BERTICS et al., 1992; GRUM et al., 1994).

Within this context, the objective of this study was to evaluate the effect of fat supplementation with different lipid source on productive performance and biochemical parameters of dairy cows during the transition period and early lactation.

\section{MATERIALS AND METHODS}

The experiment was conducted at the Research Laboratory of Dairy Cattle, School of Veterinary Medicine and Animal Science, University of São Paulo, Pirassununga - Brazil. 30 Holstein cows were used and supplemented from $28^{\circ}$ days before parturition until 12 weeks postpartum lactation with the same experimental diet, and kept in individual stalls in freestall barn.

The animals were divided into three experimental groups in a randomized design. The diets were formulated according to NRC (2001): 1) control (C), diet composed of approximately $2.5 \%$ ether extract in dry matter, without added fat sources; 2) Soybean oil (SO), diet composed of approximately $5.5 \%$ ether extract, based in addition of $3.0 \%$ refined soybean oil in the concentrate; 3 ) calcium salts of fatty acids (CS) (MEGALAC-E, General Chemistry of the Northeast and Arm \& Hammer, Inc.), diet composed of approximately $5.5 \%$ ether extract, based in inclusion of $3.0 \%$ of calcium salts of fatty acids in the concentrate. 
Different diets were formulated to meet the nutritional requirements of cows during the pre-partum and postpartum period, within each experimental group (Table 1). The concentrations of the fatty acids in the experimental diets (Table 2) also were calculated
The animals were mechanically milked twice daily, and milk yield was recorded daily throughout the trial period, and the data of milk yield corrected for $3.5 \%$ fat.

Table 1. Ingredients and composition of nutrients of the experimental diets during the pre and post-partum period

\begin{tabular}{|c|c|c|c|c|c|c|}
\hline \multirow{3}{*}{ Ingredients } & \multicolumn{6}{|c|}{ Experimental diets } \\
\hline & \multicolumn{3}{|c|}{ Pre-partum } & \multicolumn{3}{|c|}{ Post-partum } \\
\hline & $\mathrm{C}^{1}$ & $\mathrm{SO}^{2}$ & $\mathrm{CS}^{3}$ & $\mathrm{C}^{1}$ & $\mathrm{SO}^{2}$ & $\mathrm{CS}^{3}$ \\
\hline \multicolumn{7}{|l|}{$\% \mathrm{DM}$} \\
\hline Corn silage $^{4}$ & 75.02 & 75.02 & 75.02 & 47.02 & 47.02 & 47.02 \\
\hline Ground corn & 13.38 & 10.32 & 10.32 & 27.28 & 24.90 & 25.31 \\
\hline Soybean meal & 9.47 & 9.46 & 9.46 & 22.13 & 21.30 & 21.30 \\
\hline Calcium salts of fatty acids & - & - & 2.99 & - & - & 3.31 \\
\hline Soybean oil & - & 2.99 & - & - & 3.02 & - \\
\hline Urea & 0.97 & 1.05 & 1.05 & 0.39 & 0.58 & 0.58 \\
\hline Sulfate of ammonia & 0.08 & 0.08 & 0.08 & 0.05 & 0.05 & 0.05 \\
\hline Sodium bicarbonate & - & - & - & 0.81 & 0.81 & 0.81 \\
\hline Magnesium oxide & - & - & - & 0.20 & 0.20 & 0.20 \\
\hline Dicalcium phosphate & 0.08 & 0.08 & 0.08 & 0.55 & 0.55 & 0.55 \\
\hline Limestone & 0.40 & 0.40 & 0.40 & 0.99 & 0.99 & 0.29 \\
\hline Mineral $^{5}$ & 0.28 & 0.28 & 0.28 & 0.26 & 0.26 & 0.26 \\
\hline Vitamin supplement ${ }^{6}$ & 0.16 & 0.16 & 0.16 & - & - & - \\
\hline Salt & 0.16 & 0.16 & 0.16 & 0.32 & 0.32 & 0.32 \\
\hline \multicolumn{7}{|l|}{ Nutrients \% DM } \\
\hline Dry matter & 47.54 & 47.81 & 47.45 & 61.80 & 61.94 & 61.53 \\
\hline Organic matter & 92.41 & 92.58 & 91.84 & 92.51 & 92.68 & 92.84 \\
\hline Mineral matter & 7.58 & 7.41 & 8.15 & 7.49 & 7.32 & 7.16 \\
\hline Crude Protein & 15.68 & 15.12 & 15.12 & 18.79 & 18.68 & 18.72 \\
\hline Non-fibrous carbohydrate & 40.78 & 37.78 & 38.62 & 45.66 & 41.79 & 41.95 \\
\hline Ether extract & 2.73 & 5.59 & 5.05 & 2.83 & 5.69 & 5.41 \\
\hline Neutral detergent fiber & 47.21 & 46.56 & 46.56 & 36.24 & 35.60 & 35.69 \\
\hline Acid detergent fiber & 29.82 & 29.54 & 29.54 & 21.21 & 21.00 & 21.02 \\
\hline Lignin & 4.52 & 4.42 & 4.47 & 3.48 & 3.37 & 3.37 \\
\hline Total carbohydrate & 73.76 & 71.24 & 71.77 & 69.47 & 66.28 & 66.51 \\
\hline Total digestible nutrients ${ }^{7,8}$ & 66.83 & 69.61 & 68.97 & 75.55 & 76.07 & 75.67 \\
\hline Net energy of lactation ${ }^{8}$ & 1.19 & 1.26 & 1.27 & 1.68 & 1.74 & 1.76 \\
\hline \multicolumn{7}{|c|}{$\begin{array}{l}{ }^{1} \text { Control; }{ }^{2} \text { Soybean oil; }{ }^{3} \text { Calcium salts od fatty acids (Megalac-E®); }{ }^{4} \text { corn silage contains: } 34.44 \% \text { DM } \\
\text { (natural matter) and } 48.50 \% \text { NDF. } 7.50 \% \mathrm{CP} \text { and } 10.07 \% \text { mineral matter in dry matter. } 1.47 \mathrm{Net} \\
\text { energy/Kg of DM; }{ }^{5} \text { composition per kg of the product: Mg-10g; S-9g; } \mathrm{Zn}-23.750 \mathrm{mg} \text {; Cu-5625mg; Mn- } \\
\text { 18125mg; Fe-5.000mg; Co-125mg; I-312mg; Se-144mg; F (Máx.) } 900 \mathrm{mg} \text {; Vit. A- 2000ui; Vit E - } \\
\text { 12500mg; Vit D - 5000UI; }{ }^{6} \text { composition per kg of the product: Vit. A- } 8000 \mathrm{UI} \text {; Vit E- } 50000 \mathrm{mg} \text {; Vit } \\
\text { D - } 2300 \text { UI; }{ }^{7} \text { Estimated with NRC, } 2001{ }^{8} \text { Mcall/kg/DM. }\end{array}$} \\
\hline
\end{tabular}


Rev. Bras. Saúde Prod. Anim., Salvador, v.15, n.1, p.83-93 jan./mar., 2014 http://www.rbspa.ufba.br ISSN 15199940

Table 2. Fatty acids composition of the experimental diets during the pre and postpartum period

\begin{tabular}{|c|c|c|c|c|c|c|}
\hline \multirow{3}{*}{ Item } & \multicolumn{6}{|c|}{ Experimental diets } \\
\hline & \multicolumn{3}{|c|}{ Pre-partum } & \multicolumn{3}{|c|}{ Post-partum } \\
\hline & $\mathrm{C}^{1}$ & $\mathrm{SO}^{2}$ & $\mathrm{CS}^{3}$ & $\mathrm{C}^{1}$ & $\mathrm{SO}^{2}$ & $\mathrm{CS}^{3}$ \\
\hline \multicolumn{7}{|c|}{ Fatty acids ( $\mathrm{g} / 100 \mathrm{~g}$ of $\mathrm{FA})$} \\
\hline C14:0 & 0.45 & 0.45 & 0.46 & 0.34 & 0.34 & 0.35 \\
\hline C16:0 & 16.71 & 16.66 & 16.60 & 15.28 & 15.18 & 15.19 \\
\hline C18:0 & 3.16 & 3.18 & 3.14 & 3.11 & 3.12 & 3.10 \\
\hline $\mathrm{C} 18: 1 \mathrm{cis}$ & 12.35 & 12.59 & 12.61 & 12.33 & 12.56 & 12.70 \\
\hline $\mathrm{C} 18: 2(n-6)$ & 15.97 & 27.12 & 26.95 & 20.86 & 32.92 & 33.04 \\
\hline $\mathrm{C} 18: 3(n-3)$ & 1.37 & 1.31 & 1.26 & 2.93 & 2.88 & 2.87 \\
\hline Other & 3.69 & 3.68 & 3.84 & 2.74 & 2.71 & 2.88 \\
\hline
\end{tabular}

${ }^{1}$ Control; ${ }^{2}$ soybean oil; ${ }^{3}$ calcium salts of fatty acids (Megalac-E®).

Daily weight measurements were made to quantify the forage and concentrate provided and leftovers of each experimental diet, to estimate of the individual dry matter intake (DMI). The animals were fed according to the DMI in the previous day in order to be kept 5 and $10 \%$ leftovers based on fresh diet. The animals were weighed and measured the BCS weekly during the trial period ( -28 to 84 days in relation at parturition). The calculation of the energy balance was carried out according to NRC (2001). Diets were chemically analyzed following the recommendations of NRC (2001) and methodology according to AOAC (2000). Blood samples were taken weekly throughout the trial period ( -28 to 84 days in relation at parturition) for vein puncture and/or coccygeal artery, prior to morning feeding. Blood was collected in the first 24 hours after parturition. The samples were collected in tubes vacuolated (vacutainer) of 10 $\mathrm{ml}$ for dosage of the biochemical parameters.

Immediately after collection, the samples for biochemical determinations were centrifuged at $2000 \times \mathrm{g}$ for 15 minutes. The supernatant serum obtained was transferred to plastic tubes, identified and stored at $-20^{\circ} \mathrm{C}$ until the procedure of the laboratory analysis.
Blood serum was Analyzed for glucose, total cholesterol, HDL-cholesterol, total protein, albumin, urea, non-esterified fatty acids, $\beta$-hydroxybutyrate, aspartate aminotransferase, $\gamma$-glutamyl transferase, and alkaline phosphatase concentrations. These analyses were performed using commercial kits $\left(\right.$ Laborlab $^{\circledR}$, CELM $^{\circledR}$, Randox ${ }^{\circledR}$ ) using enzymatic colorimetric endpoint method or kinetic. The reading was performed in automatic biochemistry analyzer (SBA-200 automatic biochemistry - CELM ${ }^{\circledR}$ ) and microplate reader (Asys Brand, Model UV-Plus Expert).

The data were subjected to SAS Version 9.1.3. (STATISTICAL ANALYSIS SYSTEM, 2004), verifying the normality of residuals and homogeneity of variances by PROC UNIVARIATE.

Data were analyzed by PROC MIXED according to the following model of time repeated measures (LITTEL et al., 2006):

$Y i j=\mu+D i+T j+D i(T j)+e i j$

Where: Yij $=$ dependent variable; $\mu=$ overall mean; $\mathrm{Di}=$ fixed effect of diet; $\mathrm{T} j=$ variable effect of time; $\mathrm{Di}(\mathrm{Tj})=$ interaction between diet and time; eij = random error. Autoregressive method was used for calculating the covariance structure. The degrees of freedom were 
calculated according to the satterthwaite's method (ddfm = satterth).

Posteriorly orthogonal contrasts were performed, where $\mathrm{C} 1$ (control vs. fat sources) and C2 (soybean oil vs. calcium salts), and used significance level of $5 \%$.

\section{RESULTS AND DISCUSSION}

The experimental diets affected $(\mathrm{P}<0.05)$ the DMI, body weight,and energy balance in the postpartum period. DMI was different when comparing the two contrasts analyzed. Greater DMI was observed $(\mathrm{P}<0.05)$ for the control diet in relation to the others, Diet with calcium salts was grater in relation to soybean oil.
Similar results were observed for body weight (Table 3), data also present in (RENNÓ et al. 2013)

Interaction effect was significant for Fat corrected milk $(\mathrm{FCM}) \quad(\mathrm{P}<0.05)$ No difference was observed between the contrasts evaluated. Time effects were observed $(\mathrm{P}<0.05)$ for the dry matter intake, milk yield and energy balance (Figure 1). The dry matter intake and energy balance had the same behavior, presenting decline from pre-partum period until the fourth week of lactation (Figure 1a and 1b). Milk yield and 3.5\% fat corrected milk yield showed increases of the week of parturition until the $5^{\text {th }}$ and $6^{\text {th }}$ week of lactation, showing persistence until the end of the experimental period (Figure 1c).

Table 3. Productive performance in function of the experimental diets

\begin{tabular}{|c|c|c|c|c|c|c|c|c|c|}
\hline \multirow{2}{*}{ Item $^{2}$} & \multicolumn{3}{|c|}{ Experimental diets } & \multirow{2}{*}{ SEM } & \multicolumn{5}{|c|}{ Probabilities $^{3,4}$} \\
\hline & $\mathrm{C}$ & $\mathrm{SO}$ & $\mathrm{CS}$ & & Diet & Time & Int. & $\mathrm{C} 1$ & $\mathrm{C} 2$ \\
\hline DMI (kg/day) & 11.19 & 9.82 & 9.70 & 0.05 & 0.176 & $<0.001$ & 0.817 & 0.065 & 0.919 \\
\hline $\mathrm{BW}(\mathrm{kg})$ & 649.98 & 62.99 & 34.56 & 0.07 & 0.357 & 0.015 & 0.997 & 0.945 & 0.153 \\
\hline EB (Mcall/da & & 1.16 & & & & $<0$. & & & \\
\hline DMI & 18.50 & 15.06 & 17.41 & 0.07 & 0.018 & $<0.001$ & 0.156 & 0.032 & 0.049 \\
\hline MY & 32.27 & 30.46 & 30.98 & 0.03 & 0.744 & $<0.001$ & 0.138 & 0.465 & 0.829 \\
\hline FCM 3, & 31.26 & 28.05 & 26.88 & 0.04 & 0.076 & $<0.001$ & 0.003 & 0.029 & 0.543 \\
\hline BW (kg) & 596.66 & 564.94 & 592.02 & 0.07 & $<0.001$ & 0.997 & 0.999 & 0.019 & 0.002 \\
\hline EB (Mcall/day) & -2.00 & -2.75 & 0.32 & 0.18 & $<0.001$ & $<0.001$ & 0.998 & 0.083 & $<0.001$ \\
\hline
\end{tabular}

${ }^{1}$ Control. Soybean oil. Calcium salts of fatty acids (Megalac-E囚). ${ }^{2}$ Dry matter intake (DMI); body condition score (BCS); body weight (BW); energy balance (EB); mlk yield (MY); fat corrected milk $3,5 \%$ (FCM 3,5\%). ${ }^{3}$ Value of probability of the multivariate analysis considering the fixed effects of diet, time and interaction of the two variables. ${ }^{4}$ Orthogonal contrasts $\mathrm{C} 1$ (control vs. fat sources), and $\mathrm{C} 2$ (soybean oil vs. calcium salts).

The intake of dry matter in diets with fat sources was similar in the pre-partum period, so that the animals fed both diets with calcium salts of fatty acids and soybean oil began the second week prepartum with average consumption of $10.0 \mathrm{~kg} / \mathrm{DM} /$ day while the animals fed the control diet began the second week pre-partum consuming $11.0 \mathrm{~kg} / \mathrm{DM} /$ day
(Figure 1a). Santos et al. (2009) evaluated the inclusion of soybean oil in $8 \%$ of the total dry matter in diets of cows during the transition period and also did not observe changes in dry matter intake during the pre-partum period obtaining similar values to those observed in this study with a mean $10.0 \mathrm{~kg} \mathrm{DM} /$ cow/day. 
Rev. Bras. Saúde Prod. Anim., Salvador, v.15, n.1, p.83-93 jan./mar., 2014 http://www.rbspa.ufba.br ISSN 15199940


Figure 1. Dry matter intake (1a), energy balance (1b), milk yield (1c), in function of the experimental diets and time 
Duske et al. (2009) evaluated the supplementation of calcium salts of fatty acids in 80 Holstein cows with an average production of $35.0 \mathrm{~kg} / \mathrm{cow} /$ day using two diets, control diet with $2.7 \%$ of $\mathrm{EE}$ and a diet with $5.5 \%$ ether extract based on total dry matter. These authors did not observe variations in dry matter intake in close-up period obtaining average of dry matter intake similar to those observed in this study $11.10 \mathrm{~kg} / \mathrm{DM} / \mathrm{cow} /$ day.

The superiority in dry matter intake for diets with calcium salts of fatty acid in relation to diet with soybean oil can possibly be explained by the fact that calcium salts be inert in the rumen, thereby showing no deleterious effects on rumen fermentation, as can possibly occur on diets with soybean oil composed in its entirety with free fatty acids in the rumen.

The results observed for the energy balance in the post-partum period may be related to higher dry matter intake of cows of the control group and the group calcium salts of fatty acids in relation to cows of the soybean oil group (Figure $1 b)$.

Similarly, an improvement of the energy balance was found in Holstein cows fed lipogenic diet during the transition period in the study conducted by Van Knegesel et al. (2007). These authors associated this effect to a reduction in nutrient partitioning for milk fat and mobilization of body fat.

The results for milk yield and 3.5\% fat corrected milk (FCM) are closely related to dry matter intake presented by animals in post-partum According Onetti \& Grummer, (2004), the positive response to supplementation of dietary fat should be expected because of the greater availability of net energy, since reduction did not occur in dry matter intake (Figure 1c).

The experimental diets did not affect the biochemical parameters glucose, total protein, albumin, urea, serum urea nitrogen, total cholesterol, HDLcholesterol, non-esterified fatty acids, $\quad \beta$-hydroxybutyrate, aspartate aminotransferase, $\gamma$-glutamyl transferase, alkaline phosphatase, also not being observed differences between the contrasts analyzed (Table 4).

Urea and serum urea nitrogen presented interaction effect $(\mathrm{P}<0.05)$ between time and diet in pre and post-partum, however for plasma concentrations of glucose and non-esterified fatty acids only interaction $(\mathrm{P}<0.05)$ between time and diet in the post-partum was observed.

The variables total cholesterol, $\beta$ hydroxybutyrate, $\gamma$-glutamyl transferase, alkaline phosphatase were influenced by time $(\mathrm{P}<0.05)$, in both pre-partum and post-partum, however the concentrations of albumin, total protein and HDL-cholesterol only were influenced by time $(\mathrm{P}<0.05)$ in post-partum while the hepatic enzyme aspartate aminotransferase was only affected in pre-partum.

The glucose concentration showed higher in pre-partum, with decline in the parturition and in the first week postpartum, being restored to levels within the reference values from the third week of lactation (Figure 2a). Regarding nonesterified fatty acids and $\beta$ hydroxybutyrate, there was a significant increase at parturition and persisted until the third week of lactation (Figure $2 b$ and $2 c$ ).

The physiological reduction of dry matter intake, negative energy balance from the intense mobilization of body reserves as well as the immense hepatic metabolism and the homeorrhesis in nutrient partitioning for lactation seem to dictate the differences observed over the pre and postpartum periods for parameters evaluated (DRACKLEY, 1999). 
Rev. Bras. Saúde Prod. Anim., Salvador, v.15, n.1, p.83-93 jan./mar., 2014 http://www.rbspa.ufba.br ISSN 15199940

Table 4. Biochemical parameters in the pre and post-partum according to the experimental diets

\begin{tabular}{|c|c|c|c|c|c|c|c|c|c|}
\hline \multirow{2}{*}{ Item } & \multicolumn{3}{|c|}{ Experimental Diets $^{1}$} & \multirow{2}{*}{ SEM } & \multicolumn{5}{|c|}{ Probabilities $^{2,3}$} \\
\hline & $\mathrm{C}$ & $\mathrm{SO}$ & $\mathrm{CS}$ & & Diet & Time & Int. & $\mathrm{C} 1$ & $\mathrm{C} 2$ \\
\hline \multicolumn{10}{|c|}{$\mathrm{mg} / \mathrm{dL}$} \\
\hline \multicolumn{10}{|l|}{ Glucose } \\
\hline Pre-partum & 69.00 & 61.11 & 72.30 & 2.53 & 0.137 & 0.178 & 0.235 & 0.533 & 0.089 \\
\hline Post-partum & 62.78 & 62.08 & 57.81 & 2.15 & 0.394 & 0.004 & $<0.001$ & 0.352 & 0.318 \\
\hline \multicolumn{10}{|c|}{ Albumin $(\mathrm{g} / \mathrm{L})$} \\
\hline Pre-partum & 3.17 & 3.29 & 3.39 & 0.09 & 0.716 & 0.789 & 0.122 & 0.461 & 0.734 \\
\hline Post-partum & 3.25 & 3.23 & 3.15 & 0.08 & 0.880 & 0.039 & 0.220 & 0.772 & 0.683 \\
\hline \multicolumn{10}{|c|}{ Total protein $(\mathrm{g} / \mathrm{L})$} \\
\hline Pre-partum & 7.07 & 6.28 & 7.25 & 0.33 & 0.602 & 0.723 & 0.345 & 0.748 & 0.343 \\
\hline Post-partum & 8.74 & 7.86 & 8.36 & 0.34 & 0.628 & $<0.001$ & 0.649 & 0.442 & 0.583 \\
\hline \multicolumn{10}{|l|}{ Urea } \\
\hline Pre-partum & 33.78 & 33.96 & 32.96 & 1.35 & 0.959 & 0.003 & 0.022 & 0.968 & 0.778 \\
\hline Post-partum & 50.15 & 49.42 & 43.72 & 1.87 & 0.134 & $<0.001$ & 0.047 & 0.215 & 0.118 \\
\hline \multicolumn{10}{|c|}{ Serum urea nitrogen } \\
\hline Pre-partum & 15.78 & 16.05 & 15.41 & 0.61 & 0.899 & 0.001 & 0.032 & 0.943 & 0.651 \\
\hline Post-partum & 23.44 & 22.20 & 20.42 & 0.88 & 0.191 & $<0.001$ & 0.046 & 0.115 & 0.359 \\
\hline \multicolumn{10}{|c|}{ Total Cholesterol } \\
\hline Pre-partum & 95.19 & 123.62 & 110.47 & 3.84 & 0.127 & $<0.001$ & 0.171 & 0.071 & 0.346 \\
\hline Post-partum & 169.12 & 171.71 & 182.34 & 5.52 & 0.727 & $<0.001$ & 0.055 & 0.572 & 0.577 \\
\hline \multicolumn{10}{|c|}{ HDL-Cholesterol } \\
\hline pre-partum & 47.38 & 56.54 & 56.36 & 3.22 & 0.203 & 0.117 & 0.540 & 0.077 & 0.964 \\
\hline Post-partum & 86.92 & 92.01 & 95.59 & 4.96 & 0.500 & $<0.001$ & 0.451 & 0.300 & 0.584 \\
\hline \multicolumn{10}{|l|}{$\mathrm{mmol} / \mathrm{L}$} \\
\hline \multicolumn{10}{|c|}{ Non-esterified fatty acids } \\
\hline Pre-partum & 0.66 & 0.79 & 0.66 & 0.05 & 0.357 & $<0.001$ & 0.107 & 0.650 & 0.178 \\
\hline Post-partum & 0.80 & 0.87 & 0.80 & 0.06 & 0.772 & $<0.001$ & $<0.001$ & 0.666 & 0.574 \\
\hline \multicolumn{10}{|c|}{$\beta$-hydroxybutyrate } \\
\hline Pre-partum & 0.67 & 0.54 & 0.74 & 0.03 & 0.167 & 0.002 & 0.521 & 0.654 & 0.068 \\
\hline Post-partum & 0.70 & 0.59 & 0.78 & 0.06 & 0.196 & $<0.001$ & 0.639 & 0.872 & 0.075 \\
\hline \multicolumn{10}{|l|}{$\mathrm{U} / \mathrm{L}$} \\
\hline \multicolumn{10}{|c|}{ Aspartate aminotransferase } \\
\hline Pre-partum & 59.00 & 59.89 & 67.67 & 4.37 & 0.160 & $<0.001$ & 0.401 & 0.311 & 0.101 \\
\hline Post-partum & 79.83 & 87.56 & 80.93 & 5.58 & 0.712 & 0.062 & 0.133 & 0.696 & 0.492 \\
\hline \multicolumn{10}{|c|}{$\gamma$-glutamyl tranferase } \\
\hline Pre-partum & 3.61 & 3.56 & 3.68 & 0.19 & 0.907 & $<0.001$ & 0.208 & 0.985 & 0.663 \\
\hline Post-partum & 5.87 & 5.08 & 4.76 & 0.23 & 0.701 & $<0.001$ & 0.177 & 0.621 & 0.499 \\
\hline \multicolumn{10}{|c|}{ Alkaline phosphatase } \\
\hline Pre-partum & 41.62 & 34.83 & 40.40 & 1.49 & 0.554 & $<0.001$ & 0.232 & 0.486 & 0.408 \\
\hline Post-partum & 34.39 & 33.43 & 36.62 & 1.73 & 0.869 & $<0.001$ & 0.692 & 0.908 & 0.608 \\
\hline
\end{tabular}



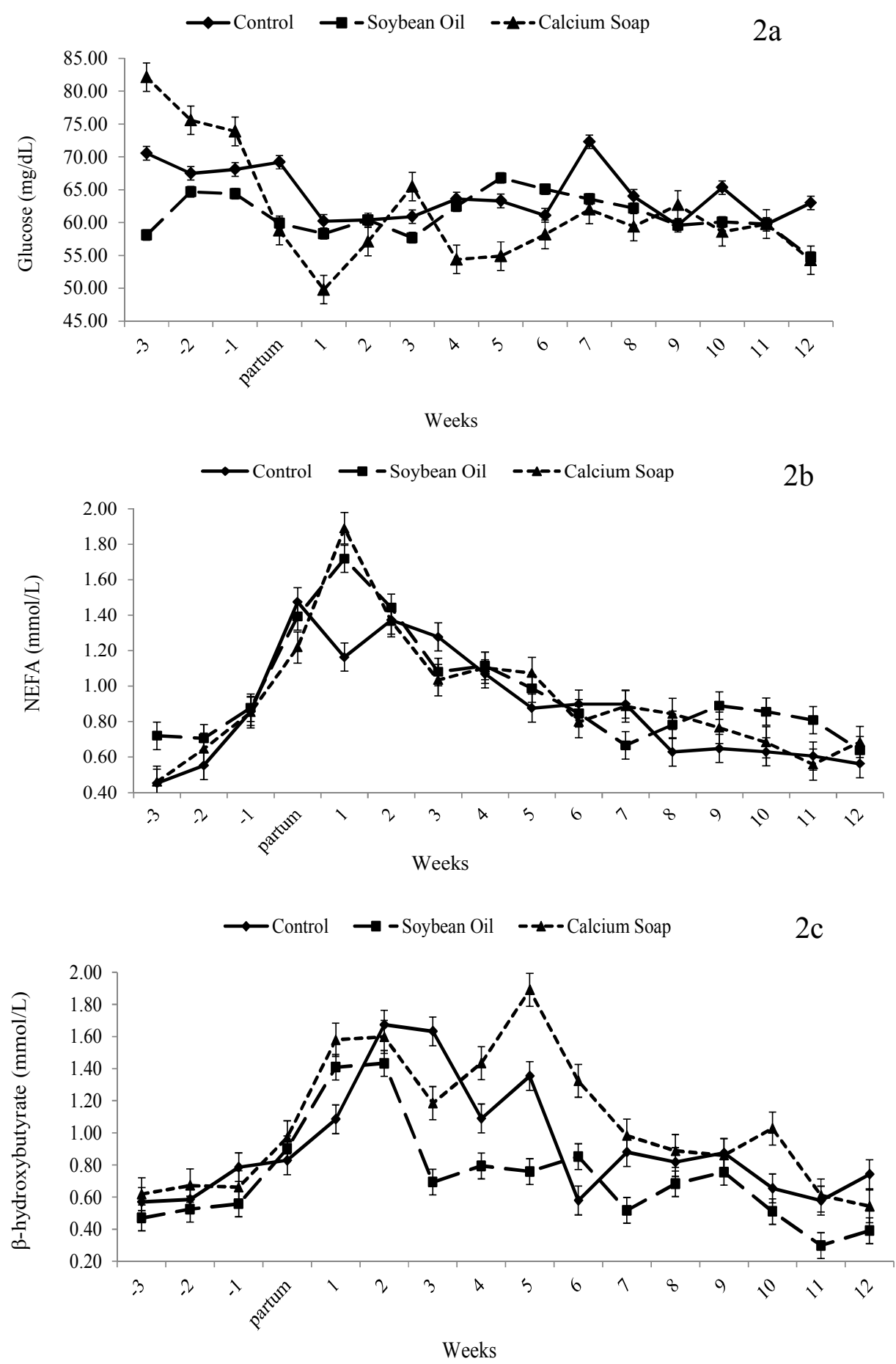

Figure 2. Glucose (2a), non-esterified fatty acids (NEFA) (2b), $\beta$ hydroxybutyrate $(2 \mathrm{c})$ in function of the experimental diets and time

The interaction observed in post-partum for glucose and non-esterified fatty acids (Figures $2 \mathrm{a}$ and $2 \mathrm{~b}$ ) may be explained partly by lower dry matter intake obtained for the rations containing fat sources when compared to the control diet and for diet with soybean oil when compared to other experimental diets in post-partum, 
because there was no reduction in milk production of animals subjected to same ration indicating greater mobilization of body fat to meet the demand of nutrients for the production of milk.

During the transition period, several hormonal changes occur mainly to regulate the parturition and early lactation, and secondarily the metabolism to adapt to these events (ADEWUVI et al., 2005; INGVARTSEN, 2006). These mechanisms produce a state of hypoglycemia after partum (BUTLER, 2005). However, it is possible that some cows have gluconeogenic effect of adrenaline and cortisol because of the excitation and stress associated with the parturition.

The increase observed for concentrations of $\beta$-hydroxybutyrate in post-partum is associated with changes in energy demand in reduction of the dry matter intake, with consequent intense lipid metabolization in the liver (Figure 2c). The reduction of cholesterol is related with the key in the synthesis of lipoproteins of the hepatocytes. In the post-partum period there is an increase in circulating of high density lipoproteins and a drastic decrease in low density lipoproteins (LDL) as well as decreases in very low density lipoproteins (QUIROZ-ROCHA et al., 2009). Low density lipoproteins contain a higher proportion of cholesterol in relation to high density (BRUSS et al., 1997).

The observed changes over time were caused mostly by natural physiological changes occurring in specialized dairy cows during the transition period and early lactation. However, fat supplementation in the transition period resulted in a better metabolic status and productive performance, mainly improving energy balance post-partum.

\section{REFERENCES}

\author{
ASSOCIATION OF OFFICIAL \\ ANALYTICAL CHEMISTS - AOAC. \\ Official Methods of Analysis. $17^{\text {th }} \mathrm{ed}$. \\ Gaithersburg, 2000.
}

\author{
ADEWUYI, A.A.; GRUYS, E.; Van \\ EERDENBURG, F.J.C.M. Non \\ esterified fatty acids (NEFA) in dairy \\ cattle. A review. Veterinary Reviews, \\ v.27, p.117-126, 2005. \\ BERTICS, S.J.; GRUMMER, R.R.; \\ CADORNIGA-VALINO, C.; \\ STODDARD, E.E. Effect of prepartum \\ dry matter intake on liver triglyceride \\ concentration and early lactation. \\ Journal of Dairy Science, v.75, \\ p.1914-1922, 1992.
}

BRUSS, M.L. Lipids and ketones. In: KANEKO, J.J.; HARVEY, J.W.; BRUSS, M.L. (Eds.). Clinical Biochemistry of Domestic Animals. 5thed. San Diego: Academic Press, 2007. p.83-115.

BUTLER, W.R. Nutrition, negative energy balance and fertility in the postpartum dairy cow. Cattle Practice, v. 13, p.13-18, 2005.

DRACKLEY, J.K. Biology of dairy cows during the transition period: the final frontier. Journal of Dairy Science, v.82, p.2259-2273, 1999.

DUSKE, K.; HAMMON, H.M.; LANGHOF, A.K.; BELLMANN, O.; LOSAND, B.; NÜRNBERG, K.; NÜRNBERG, G.; SAUERWEIN, H.; SEYFERT, H.M.; METGES, C.C. Metabolism and lactation performance in dairy cows fed a diet containing rumen-protected fat during the last twelve weeks of gestation. Journal of Dairy Science, v.92, p.1670-1684, 2009. 
GRUM, D.E., HANSEN, L.R., DRACKLEY, J.K. Peroxisomal \& oxidation of fatty acids in bovine and rat liver. Comparative Physiology and Biochemical, v.109, p.281-292, 1994.

INGVARTSEN, K.L. Feeding- and management-related diseases in the transition cow: Physiological adaptations around calving and strategies to reduce feeding-related diseases. Animal Feed Science and Technology, v.126, p.175-213, 2006.

NATIONAL RESEARCH COUNCIL NRC. Nutrient requirements of dairy cattle. 7.ed. Washinton, D.C.: National Academic Press, 2001. 381p.

ONETTI, S.G.; GRUMMER, R.R. Response of lactating cows to three supplemental fat sources as affected by forage in the diet and stage of lactation: a meta-analysis of literature. Animal Feed Science and Technology, v.115, p.65-82, 2004.

QUIROZ-ROCHA, G.F., LEBLANC, S.J.; DUFFIELD, T.F.; WOOD, D.; LESLIE, K.E.; JACOBS, R.M. Reference limits for biochemical and hematological analytes of dairy cows one week before and one week after parturition. Canadian Journal Veterinary Research, v. 12, p.225-232, 2009.

RENNÓ, F.P.; FREITAS JÚNIOR, J.E.; GANDRA,J.R.; VERDURICO,L.C.; SANTOS,M.V.; BARLETTA,R.V.; VENTURELLI,B.C.; VILELA,F.G. Fatty acid profile and composition of milk protein fraction in dairy cows fed long-chain unsaturated fatty acids during the transition period. Revista Brasileira de Zootecnia, v.42, p.813823, 2013
SANTOS, A.D.F.; TORRES, C.A.A.; RENNÓ, F.R.; DRUMOND, M.R.S.; FEITAS JUNIOR, J.E. Use of soybean oil for dairy cows during transition period: Intake, milk yield and composition. Revista Brasileira de Zootecnia, v.38, p.1363-1371, 2009.

STATISTICAL ANALYSIS SYSTEM. User's Guide. Release 9.1. Cary: SAS Institute, 2004.

SILVESTRE, F.T.; CARVALHO, T.S.M.; CRAWFORD, P.C.; SANTOS, J.E.P.; STAPLES, C.R.; JENKINS, T.; THATCHER, W.W. Effects of differential supplementation of fatty acids during the peripartum and breeding periods of Holstein cows: II. Neutrophil fatty acids and function, and acute phase proteins. Journal of Dairy Science, v.94, p.2285-2301, 2011.

VAN KNEGSEL, A. T. M.; VAN DEN BRAND H.; DIJKSTRA, J.; VAN STRAALEN, W. M.; HEETKAMP, M. J.; TAMMINGA, S.; KEMP, B. Dietary energy source in dairy cows in early lactation: energy partitioning and milk composition. Journal of Dairy Science, v. 90, p.1467-1476, 2007.

ZACHUT, M.; ARIELI, A.; LEHRER, H.; LIVSHITZ, L.; YAKOBY, S.;

MOALLEM, U. Effects of increased supplementation of n-3 fatty acids to transition dairy cows on performance and fatty acid profile in plasma, adipose tissue, and milk fat. Journal of Dairy Science, v.93, p.5877-5889, 2010.

Data de recebimento: 24/09/2013

Data de aprovação: 13/03/2014 